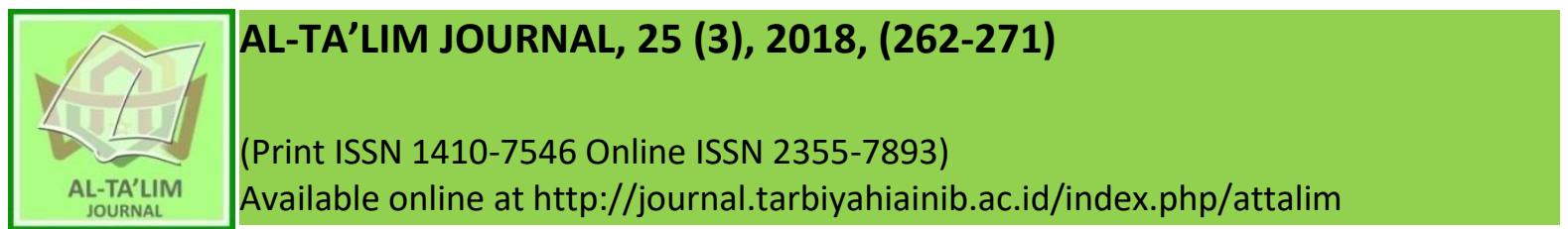

\title{
The Utilization of Project Based Learning and Guided Discovery Learning: Effective Methods to Improve Students' Mathematics Ability
}

Received: $07^{\text {th }}$ July 2018; Revised: $04^{\text {th }}$ September 2018; Accepted: $26^{\text {th }}$ November 2018

Permalink/DOI: http://dx.doi.org/10.15548/jt.v25i3.487

\section{Nanang Supriadi}

Universitas Islam Negeri Raden Intan Lampung, Indonesia

E-mail: nanangsupriadi@gmail.com

\section{Muhamad Syazali*}

Universitas Islam Negeri Raden Intan Lampung, Indonesia

E-mail:

muhamadsyazali@radenintan.ac.id

\section{Bella Dwi Lestari*}

Universitas Islam Negeri Raden Intan Lampung, Indonesia

E-mail: b.dwilestari@yahoo.com

\section{Eva Sima Dewi*}

Universitas Islam Negeri Raden Intan Lampung, Indonesia

E-mail: evasima8@gmail.com

\section{Lintang Fitra Utami*}

Universitas Islam Negeri Raden Intan Lampung, Indonesia

E-mail: lintangfitrautami87@gmail.com

\section{Lingga Afriansyah Mardani* \\ Universitas Islam Negeri Raden Intan \\ Lampung, Indonesia \\ E-mail: \\ afriansyahlingga1996@gmail.com}

\section{*) Corresponding Author}

\begin{abstract}
The purpose of this study was to determine whether there is any difference between students' mathematical representation ability who were taught by using the learning model of Project Based Learning with students who were taught by Guided Discovery Learning; there is any difference in the students' mathematical representation ability based on high, medium, or low learning motivation categories, and there is an interaction between the learning model and the learning motivation toward mathematical representation ability. A quasi experiment was used with $2 \times 3$ factorial designs. Instrument used to collect data was mathematics test and learning motivation questionnaire. The hypothesis testing used two way analysis of variance with unequal cell. Based on the results of hypothesis testing, it can be concluded that there is a difference in the students' mathematics ability that was taught by using Project Based Learning model with students who were taught by sing Guided Discovery Learning model; there is a difference in the students'mathematical representation ability based on high, medium, or low learning motivation; and there is an interaction between the learning model and the learning motivation on the mathematics ability.
\end{abstract}

Keywords: Project Based Learning; Guided Discovery Learning; Mathematical Representation Ability; Learning Motivation

How to cite: Supriadi, N., Syazali, M., Lestari, B., Dewi, E., Utami, L., Mardani, L., \& Putra, F. (2019). The Experimentation of Project Based Learning (PjBL) and Guided Discovery Learning (GDL) Learning Model towards Mathematical Representation Ability Observed from Learning Motivation. Al-Ta Lim Journal, 25(3). doi:http://dx.doi.org/10.15548/jt.v25i3.487 


\section{INTRODUCTION}

One of the basic skills for understanding mathematics is the mathematical representation ability. The representation ability is highly recommended in mathematics learning (Garderen, Scheuermann, Poch, \& Murray, 2016). This ability is one of the priorities that must be developed in learning mathematics to build an understanding of concepts and mathematical proficiency that cannot be separated in mathematics learning (Oktaviyanthi \& Supriani, 2017; Syafri, 2017) The mathematical representation ability is still considered a problem because many learners who have difficulties in visualizing (Fatmaryanti \& Sarwanto, 2015; Garderen et al., 2016; Krawec, 2014) Lack of student representation development (Hutagol, 2013) students cannot represent the mathematical problems into mathematical expressions or images so that learners cannot solve the problem (Yusnita, Masykur, \& Suherman, 2016) Nowadays, there are many learning models that can be used for maximizing the learning, some of them are Project Based Learning (PBL) and Guided Discovery Learning (GDL) models. The PBL model is a model that requires the students to be active throughout the process and teachers lead the process, provide feedback to the students and assess performance. Passive student inclinations was activated through projectbased activities (Kimsesiz \& Konca 2017; Mulyadi 2015) While the GDL model is a model of discovery, in the process of teaching and learning teachers allow students to find their own information that can be traditionally notified or lectured only. (Hasibuan, Irwan, \& Mirna, 2014, Jumhariyani, 2016) Besides the learning model, motivation is also one of the causes of success or failure of learning (Sriwidiarti, 2016) If the motivation is strong enough then he/she will decide to do learning activities. Conversely, if the motivation is not strong enough then he/she will decide not to do learning activities, because the motivation arises from within or from outside the self. (Badrun \& Hartono, 2013; Farhan \& Retnawati, 2014)

A number of studies have been conducted to measure the effect of Project Based Learning Model and Guided Discovery Learning Model towards motivation and learning outcomes, attitudes and learning outcomes, mathematical communication skills, problem solving skills, process skills, critical thinking skills, creative thinking of mathematics. (Ambarwati, Dwijanto, \& Hendikawati, 2015, Maghfiroh, Susilo, \& Gofur, 2016 Mahanal, Darmawan, Corebima, \& Zubaidah, 2009; Muslim, 2017; Noviyana, 2017; Pratama \& Prastyaningrum, 2016; Ramadhani, 2017; Salu, 2013, Susanawati, Diantoro, \& Yuliati, 2013; Susanti, Musdi, \& Syarifuddin, 2017; Tafakur \& Suyanto, 2015; Widayati, Suyono \& Rahayu, 2018)

Based on the research that has been done before, the update in this research lies in the use of PBL and GDL model to measure the ability of mathematical representation and review it from learning motivation. The purpose of this study is to compare the model of PBL and GDL to the mathematical representation ability observed from learning motivation.

\section{METHOD}

This research type was quasi experiment. This research was a quasi experimental research with research design was using $2 \times 3$ factorial that can be described in Table 1 as follows:

Table 1. Research Factorial Design

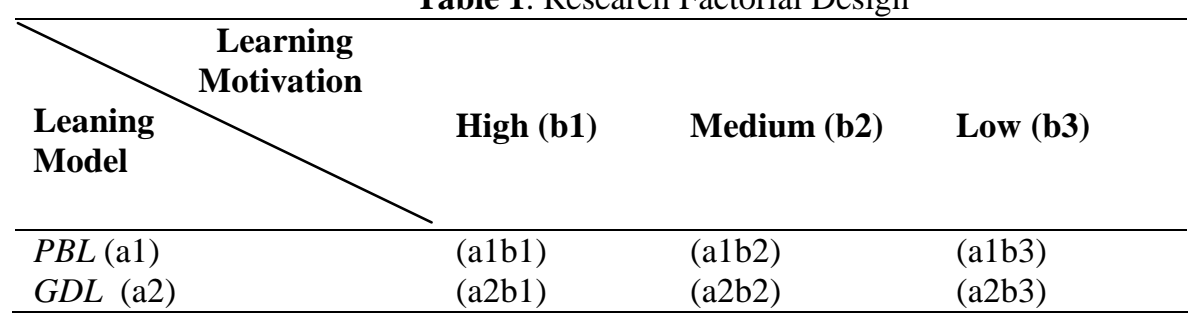


The data collection methods used tests and questionnaires, the test questions with indicators of the mathematical representationability, and questionnaires were used to determine the data about learning motivation. In determining the questionnaire scores, each alternative answer has the same score. Analysis of hypothesis test data used using the test of Two Path Anava with Cell Not Same, with hypothesis as follows:

H0: There is no difference in the students' mathematical representation ability taught by using PBL model with the students taught by using GDL model

H1: There is a difference in the students' mathematical representation ability taught by the PBL model with students taught by the GDL model

The second hypothesis,

H0: There is no difference in the students' mathematical representationability based on high, medium, or low learning motivation categories

H1: There is a difference in the students' mathematical representation ability based on high, medium, or low learning motivation categories

The third hypothesis,

$\mathrm{H} 0$ :There is no interaction between the learning model and the motivation to learn on the ability of mathematical representation
$\mathrm{H} 1$ :There is an interaction between learning model and learning motivation toward the ability of mathematical representation

Criterion of withdrawal if the value of sig. $<0.05$ then $\mathrm{H} 0$ is rejected.

Before testing using two way anava, we did the prerequisite test first i.e the normality and homogeneity test. Normality test used kolmogorov smirnov test, with test hypothesis

H0: Data is normally ditributed

H1: Data is not normally distributed

It was said to be normally distributed if the value of Sig. > 0.05 then H0 accepted or second data was normally distributed, while for homogeneity test used Levene test with hypothesis test

H0: Data is homogeneous

H1: Data is not homogeneous

It was said to be homogeneous distributed if the value of Sig. > 0.05 then H0 is accepted, and the data was homogenously distributed.

\section{RESULTS AND DISCUSSIONS}

This is the result of mathematical representation ability test on model of PBL and GDL. The results of descriptive data were presented in Table 2.

Table 2. Factorial Design Research

\begin{tabular}{cccccccc}
\hline $\begin{array}{c}\text { Representetion } \\
\text { Ability }\end{array}$ & Mean & Median & Variance & $\begin{array}{c}\text { Deviation } \\
\text { Standard }\end{array}$ & Minimum & Maximum & Range \\
\hline Model PBL & 61.8750 & 60.000 & 88.306 & 9.39715 & 45.00 & 85.00 & 40.00 \\
Model GDL & 56.5000 & 55.000 & 86.466 & 9.29868 & 35.00 & 75.00 & 40.00 \\
\hline
\end{tabular}

Descriptive data in Table 2 showed that in the PBL and GDL models, the mean, median, variance, std deviation, minimum, maximum, and range scores were obtained. The mean score for the PBL model is 61.8750 while for the GDL model 56.5000, median value score for PBL model is 60.000 while for GDL model that is 55.000 , variance value value for model PBL is 88.306 while GDL model is 86.466 , Std.Deviation value value for model PBL is 9.39715 while GDL model is 9.29868 , minimum score value for model PBL is 45.00 while for GDL model is 35.00 , maximum score for model of PBL is 85.00 while for GDL model is 75.00 , value range value for model PBL is 40.00 and for GDL model has score value 40.00. The data showed that the mean, variance, Std.Deviation, minimum, and maximum scores on the PBL model were bigger than the 
GDL model, but the value of the two models has the same value of 40.00 . Prior to the twotrack Anava test, a prerequisite test for hypothesis testing was performed. The prerequisite test includes normality and homogeneity test. The normality test of mathematical representation ability is presented in Table 3.

Table 3. Normality Test Results Ability of Mathematical Representation

\begin{tabular}{rrrrc}
\hline & & \multicolumn{3}{c}{ Kolmogorov-Smirnov } \\
& Model & Statistic & df & Statistic \\
\hline \multirow{2}{*}{ Result } & Model PBL & .142 & 32 & .102 \\
& Model GDL & .124 & 30 & .200 \\
\hline
\end{tabular}

Table 3 showed that the results of normality tests on the ability of mathematical representation on the PBL and GDL models. Based on Table 3 it is found that in the PBL model, we get the sig value. $=0.102$ then the sig value. $>0.05$ while for the GDL model obtained sig value $=0.200$ then the value of sig. > 0.05 It showed that in the model PBL and GDL, both have sig value. $>0.05$ it can be concluded that $\mathrm{H} 0$ received or both data was normally distributed. After the test of Normality, followed by Homogeneity test presented in Table 4.

Table 4. Homogeneity Test Results Ability of Mathematical Representation

\begin{tabular}{llcccc}
\hline & & Levene Statistic & df1 & df2 & Sig. \\
\hline \multirow{2}{*}{ Result } & .017 & 1 & 60 & .897 \\
& Based on Mean & .044 & 1 & 60 & .835 \\
& Based on Median & .044 & 1 & 59.215 & .835 \\
& Based on Median and with adjusted df & .027 & 1 & 60 & .870 \\
\hline
\end{tabular}

Homogeneity test towards mathematical representation ability on PBL and GDL model, obtained that sig value. = 0.897 , meaning value $>\mathrm{s}>0.05$ then $\mathrm{HO}$ is accepted, and the data is homogeneously distributed, so it can be concluded the data comes from the normal and homogeneous distribution. After the prerequisite test of Anava has been fulfilled then done Anova Test Two Paths with Cell Not Equal.

Table 5. Test Results Anava two-way mathematical representation capability

\begin{tabular}{lccccc}
\hline \multicolumn{1}{c}{ Source } & $\begin{array}{c}\text { Type III Sum } \\
\text { of Squares }\end{array}$ & df & Mean Square & F & Sig. \\
\hline Model & 959.820 & 1 & 959.820 & 14.172 & .000 \\
Motivation & 594.676 & 2 & 297.338 & 4.390 & .017 \\
Model*Motivasi & 909.464 & 2 & 454.732 & 6.714 & .002 \\
\hline
\end{tabular}

Based on Table 5 it can be concluded that on the model used because the sig value. $<0.05$ that is $<0.05$ then there was a difference in the students' mathematical representationability that was taught by using the learning model of Project Based Learning with the students taught by Guided Discovery Learning model, on the motivation with the sig value. $<0.05$ ie $.017<0.05$ then there is a difference in the ability of students' mathematical representation based on high, medium, or low learning motivation categories. On the relationship model and learning motivation with sig value $<0.05$ ie $.002<0.05$ there is an interaction between the learning model and the learning motivation on the ability of mathematical representation with the sig value. $<0.05$ ie $.002<0.05$. Furthermore, 
Table 4. Two-way Anova Test Results on Motivation

\begin{tabular}{|c|c|c|c|c|c|c|c|}
\hline \multirow{2}{*}{$\begin{array}{l}\text { Motivasi } \\
\text { (I) }\end{array}$} & \multirow{2}{*}{\multicolumn{2}{|c|}{ Motivasi }} & \multirow{2}{*}{$\begin{array}{c}\text { Mean } \\
\text { Difference } \\
\text { (I-J) }\end{array}$} & \multirow[b]{2}{*}{ Std.Error } & \multirow[b]{2}{*}{ Sig. } & \multicolumn{2}{|c|}{$\begin{array}{l}\text { 95\% Confidence } \\
\text { Interval }\end{array}$} \\
\hline & & & & & & $\begin{array}{l}\text { Lower } \\
\text { Bound }\end{array}$ & $\begin{array}{l}\text { Upper } \\
\text { Bound }\end{array}$ \\
\hline \multirow[t]{6}{*}{ Tukey HSD } & Low & Medium & -.9753 & 2.24133 & .901 & -6.3714 & 4.4209 \\
\hline & & High & $-9.1964 *$ & 3.29915 & .020 & -17.1393 & -1.2535 \\
\hline & Medium & Low & .9753 & 2.24133 & .901 & -4.4209 & 6.3714 \\
\hline & & High & $-8.2212 *$ & 3.32723 & .043 & -16.2317 & -.2106 \\
\hline & High & Low & 9.1964* & 3.29915 & .020 & 1.2535 & 17.1393 \\
\hline & & Medium & $8.2212 *$ & 3.32723 & .043 & .2106 & 16.2317 \\
\hline
\end{tabular}

Based on Table 4 it can be concluded that there was a difference in the students" mathematical representation ability with low and high motivation with average difference 9.1964, there was difference of mathematical representation ability of students with low and high motivation with mean difference 8.2212, there was different ability of mathematical representation students with high and low motivation, with an average difference of 9.1964 and there was a difference in the ability of mathematical representation of students with high and medium motivation with an average difference -8.2212.

The representation ability related to the solving problem ability both in mathematics and real life which consists of mathematical reasoning, mathematical communication, mathematical problem solving, concept comprehension, mathematical understanding, creative thinking, and critical thinking. (Arnidha, 2016; Farhan \& Retnawati, 2014; Syafri, 2017).

The mathematical representation ability is used as a tool to find solutions to problems. The importance of the ability of mathematical representation can be seen from the standard of representation established by NCTM which stipulates that learning programs from pre-kindergarten to grade 12 should enable learners to: (1) create and use representations to organize, record and communicate mathematical ideas (2) selecting, applying, and translating mathematical representations to solve problems; and (3) using representations to model and interpret physical, social, and mathematical phenomena. Therefore, mathematical representation ability required learners to find and make a tool or way of thinking in communicating mathematical ideas from the abstract to the concrete, so it is easier to understand. (Yusnita et al., 2016).

There was differences in students' Mathematical Representation Ability with PBL learning model and with GDL learning model, based on previous research PBL and GDL learning model was an effective learning model. (Imawan, 2015) PBL learning model and GDL learning model effective against some attitudes and abilities needed in learning.

The PBL model was effective against students' mathematical and confident communication skills. This is because: (1) the students' mathematical communication ability of the experimental class reached the individual KKM, (2) the students' mathematical communication ability of the experimental class reached the classical KKM, (3) the students' mathematical communication ability of the experimental class more than the students' mathematical communication ability of the control class, 4) students' confidence in experiment class was better than students' confidence in control class. (Ambarwati et al., 2015) The PBL model influenced the attainment of the student skill process, with considerable improvement (Maghfiroh et al., 2016). There was an influence of PBL learning strategies on improving student attitudes, and the PBL 
model influences conceptual understanding (Mahanal et al., 2009) The PBL model has a positive effect on the students' mathematical problem solving ability, the learning independence of learners in the mathematics learning using the PBL model is included in the high category. (Muslim, 2017) The test average of students' creative thinking ability by applying PBL learning model was higher than students that applied conventional learning model. (Noviyana, 2017) so that, the PBL model is strongly recommended for use in learning.

Besides PBL model, the GDL model is also very influential in the learning process. The GDL model has an effect on the improvement of the students' ability to understand the concept and the ability to solve the mathematics problem. The students applied the GDL model have higher ability than students who get conventional learning (Ramadhani, 2017) Students' critical thinking result who learn by using guided discovery learning model is higher than learners who learn with guided inquiry learning model and conventional learning (Widayati et al., 2018)

PBL and GDL Learning Model are the same learning model that equally effective in a learning, can improve the ability of students, but for the ability of mathematical representation in this study students using the model PBL have a higher mathematical representation capabilities compared with the GDL model, which is seen from the value the average PBL model with a value of 61.8750 and the GDL model with a value of 56.5000 . This is related to previous research that the PBL model has a positive effect in learning (Mulyadi, 2015; Sadeghi, Biniaz, \& Soleimani, 2016)

The PBL ((Project Based Learning) is a learning model that provides an opportunity for the educator to manage classroom learning by involving project work involving complex tasks based on problems. These problems are given to learners as steps in collecting and integrating knowledge new experiences based on actual experience, and demands learners to design activities, conduct investigation, solve problems, make decisions, and provide opportunities for learners to work independently or in groups. The last result of the project work was a product that includes written reports, presentations or recommendations. Assessment of project tasks was carried out from the planning process, project execution tasks to the final outcome of the project. Stages in the PBL model consist of (1) Project Determination (2) Project Completion Design (3) Schedule Setup (4) Monitoring (5) Testing Results and Presentations (6) Evaluation of Projects and Results (Mulyadi, 2015)

In the PBL model, students are required to be active and able to independently perform the tasks and develop students' creativity. One of the advantages of PBL learning model is that students can develop independence beyond the supervision of teachers to enable students to develop the independence independently. Learning activities with the PBL model keep students busy with existing projects so that they can enjoy every learning activity that is organized, although not all like it, but the impact of the PBL learning model can help overcome the learner's doubts in mathematics learning and can foster the spirit of learning. The projectbased learning model not only improves the enthusiasm, intensity and students skill in following the learning activities but also helps in improving understanding of the subject matter provided.

Guided Discovery Learning (GDL) or guided discovery is a learning model that creates learning situations that involve students learning actively and independently in finding a concept or theory, understanding, and problem solving. The discovery process requires teachers as facilitators and mentors. The amount of assistance provided by the teacher does not affect the student to make his own discovery, the instructional model of discovery performed by the student based on the teacher's instructions. The guidance given is generally in the form of a guiding statement. This model is a model of learning from the many existing learning models, 
placing teachers as facilitators, teachers guide students where teachers are needed. In this model, students are encouraged to think for themselves so that they can find general principles based on material or data provided by the teacher. With this guided discovery model, it is expected to change the learning style of the students so that the students become active in the learning. The extent to which students are guided depends on their ability and the material being studied. Application of the GDL model can also increase student enthusiasm. GDL model steps are (1) stimullation / stimulus (giving questions or encouraging students to observe or read material books), (2) problem statement (giving students opportunities to identify problems relevant to the material (3) data collection (students are given the opportunity to gather information). From the data provided by the teacher, the students arrange, process, organize, and analyze the data. In this case, teacher guidance can be given to what extent is necessary. This guidance should direct the students to move in the direction they want to go, through the questions (4) data processing (processing the data already obtained by the students) (5) verification (checking accurately to prove the correctness of the hypothesis) students preparing the conjecture of the results of the analysis done. Students compile data obtained in a data. Students who are able to obtain answers from the problem asked to check the correctness of the problem obtained using the existing data. While, they have not able yet get guidance in the form questions for the preparation of existing data. The purpose of the data compiled in a list is that students can obtain examples of answers from some existing problems and (6) generalization / generalization (make a conclusion). After students find what they are looking for, the teacher should provide additional exercise questions or questions to know whether the findings are true (Hidayat, Mulyati, \& Qohar, 2017) Some advantages in using the GDL model, namely: Learners active in learning activities, because they thinks and uses the ability to find the final result, learners understand the true subject matter experiencing the process of finding it. Something acquired in this way is longer remembered, Finding alone gives rise to a sense of satisfaction. This inner satisfaction encourages another discovery until the interest of learning increases, learners who acquire knowledge by discovery method will be better able to transfer their knowledge to various contexts, this method trains learners to learn more on their own, however some shortcomings of GDL model is for certain subject, the remaining time is longer, not all students can follow the lesson in this way. Some students are still familiar and easy to understand by lecture method and not all suitable topics are presented with this model.

The application of innovative model aimed as improving the quality of learning mathematics. Model PBL and GDL influence student motivation. Motivation is a strength in a person to do certain goals to be achieved. The purpose is something outside the human self so that human activities more focused because someone will try more spirit and enterprising in doing something. Motivation to learn can arise because of intrinsic factors, in the form of desire and desire to succeed and the impulse of learning needs, hope will be ideals. The extrinsic is award, a conducive learning environment, and interesting activities. However, these two factors are caused by certain stimuli, so that someone wants to do more vigorous learning activities and the spirit of Motivation and learning are two things that affect each other. Learning is a relatively permanent change in behavior and potentially occurs as a result of a practice or strengthening based on a goal to achieve a particular goal. The essence of learning motivation is internal and external encouragement to students learning to make changes in behavior, generally with some supportive indicators. It has a great role in the success of a person in learning (Badu Kusuma \& Utami, 2017). Based on these two elements of motivation as the basis of a good beginning to learn, because without motivation (do not understand what will be learned and do not understand why it need to be learned) 
teaching and learning activities are difficult to succeed.

In the PBL model, the learning is done collaboratively and training the students in socializing work in a group or by themselves. The students' motivation to work on this project is very strong, because the students tend to want to complete the task given even when the learning time has run out. This can also be due to the PBL stage consisting of the task-giving phase, the task implementation phase, and the task-responsible phase, so that students are required to be active and independent in doing the task. In addition, the method of assigning tasks can also develop students' creativity, develop thinking patterns and skills. This condition makes the students' motivation increase.

In the GDL model, students are directly involved in finding concepts or formulas, then engaging students to participate and participate actively through discussions. In addition, the GDL model helps students to strengthen and increase their own confidence with the discovery process themselves. Students also acquire knowledge that is personal / individual so that can be firmly left behind in the soul of the student. Thus able to raise the spirit of student learning, so that students have a stronger motivation to learn (Sriwidiarti, 2016)

Based on the information above and supported by the results of research, it can be concluded that there is interaction between model PBL and GDL and learning motivation.

\section{CONCLUSIONS AND RECOMMENDATIONS}

Based on the presented results, there are differences between the students' mathematical representation ability that was taught by using the learning model of Project Based Learning with the students taught by using Guided Discovery Learning model, there are differences in students' mathematical representation based on high, medium or low learning motivation categories, and there is interaction between learning model and learning motivation on the ability of mathematical representation.

Based on the conclusions of this study, some suggestions may be proposed for next researchers. They are expected to examine the problem with a wider range for the development of science in the world of research. In the next research, they should can try to use other learning models to maximize the ability of mathematical representation, or can use the PBL and GDL model to measure the ability of other abilities that exist in the learning of mathematics, and not just in terms of learning motivation but can be reviewed from another aspect.

\section{REFFERENCES}

Ambarwati, R., Dwijanto, \& Hendikawati, P. (2015). Keefektifanmodel Project-Based Learning Berbasis GQM Terhadap Kemampuan Komunikasimatematis Dan Percaya Diri Siswa Kelas VII. Unnes Journal of Mathematics Education, 1(1), 180-186.

Arnidha, Y. (2016). Peningkatan Kemampuan Representasi Matematis Melalui Model Pembelajaran Kooperatif Think Pair Share. Jurnal E-DuMath, 2(1), 128-137.

Badrun, \& Hartono. (2013). Keefektifan Metode Pembelajaran Kooperatif Model STAD Ditinjau dari Prestasi dan Motivasi Belajar Siswa di Kelas VIII SMP. Pythagoras: Jurnal Pendidikan Matematika, 8(2), 120-134.

Badu Kusuma, A., \& Utami, A. (2017). Penggunaan Program Geogebra dan Casyopee dalam Pembelajaran Geometri Ditinjau dari Motivasi Belajar Siswa. Jurnal Mercumatika, 1(2), 119-131.

Farhan, M., \& Retnawati, H. (2014). Keefektifan PBL Dan IBL Ditinjau dari Prestasi Belajar, Kemampuan Representasi Matematis, dan Motivasi Belajar. Jurnal Riset Pendidikan Matematika, 1(2), 227-239. 
Fatmaryanti, S. D., \& Sarwanto. (2015). Profil Kemampuan Representasi Mahasiswa Pendidikan Fisika Universitas Muhammadiyah Purworejo. JPFK, 1(1), 20-22.

Garderen, D. Van, Scheuermann, A., Poch, A., \& Murray, M. M. (2016). Visual Representation in Mathematics : Special Education Teachers' Knowledge and Emphasis for Instruction. Teacher Education and Special Education, 1(17), $1-17$.

Hasibuan, H., Irwan, \& Mirna. (2014). Metode Penemuan Terbimbing Pada Pembelajaran Matematika Kelas XI IPA SMAN 1 Lubuk Alung. Jurnal Pendidikan Matematika, 3(1), 38-44.

Hidayat, T., Mulyati, S., \& Qohar, A. (2017). Penerapan Metode Penemuan Terbimbing di Kelas VIII SMP. Jurnal Pendidikan Teori, Penelitian, Dan Pengembangan, 2(8), 1116-1122.

Hutagol, K. (2013). Pembelajaran Kontekstual Untuk Meningkatkan Kemampuan Representasi Matematis Siswa Sekolah Menengah Pertama. Jurnal Ilmiah Program Studi Matrmatika STKIP Siliwangi Bandung, 2(1), 85-99.

Imawan, O. R. (2015). Perbandingan Antara Keefektifan Model Guided Discovery Learning dan Project-Based Learning pada Matakuliah Geometri. Pythagoras: Jurnal Pendidikan Matematika, 10(2), 179-188.

Jumhariyani. (2016). Pengaruh Metode Penemuan Terbimbing Dan Kemampuan Berpikir Kritis Terhadap Kemampuan Matematika Siswa Kelas IV SD Sekecamatan SetiaBudi Jakarta Selatan. Jurnal Pendidikan Dasar, 7(1), 62-73.

Kimsesiz, F., Dolgunsoz, E., \& Konca, M. Y. (2017). The Effect of Project Based Learning in Teaching EFL Vocabulary to Young Learners of English: The Case of Pre-school Children. International
Journal of Languages Education and Teaching, 5(1), 426-439.

Krawec, J. L. (2014). Problem Representation and Mathematical Problem Solving of Students of Varying Math Ability. Journal of Learning Disabilities, 47(2), 103-115.

Maghfiroh, N., Susilo, H., \& Gofur, A. (2016). Pengaruh Project Based Learning Terhadap Kerampilan Proses Sains Siswa Kelas X Sma Negeri Sidoarjo. Jurnal Pendidikan, 1(8), 1588-1593.

Mahanal, S., Darmawan, E., Corebima, ) A D, \& Zubaidah, S. (2009). Pengaruh Pembelajaran Project Based Learning (PBL) pada Materi Ekosistem terhadap Sikap dan Hasil Belajar Siswa SMAN 2 Malang.

Mulyadi, E. (2015). Penerapan Model Project Based Learning untuk Meningkatan Kinerja dan Prestasi Belajar Fisika Siswa SMK. Jurnal Pendidikan Teknologi Dan Kejuruan, 22(4), 385-395.

Muslim, S. R. (2017). Pengaruh Penggunaan Model Project Based Learning Terhadap Kemampuan Pemecahan Masalah Matematis Peserta Didik SMA. Supremum Journal of Mathematics Education (SJME), 1(2), 88-95.

Noviyana, H. (2017). Pengaruh Model Project Based Learning Terhadap kemampuan Berfikir Kreatif Matematika Siswa. Jurnal E-DuMath, 3(2), 110-117.

Oktaviyanthi, R., \& Supriani, Y. (2017). Representasi matematis mahasiswa bertipe kepribadian sanguinis. JPPM, 10(1), 108-114.

Pratama, H., \& Prastyaningrum, I. (2016). Pengaruh Model Pembelajaran Project Based Learning Berbantuan Media Pembelajaran Pembangkit Listrik Tenaga Mikrohidro Terhadap Kemampuan Berpikir Kritis. Jurnal Penelitian Fisika Dan Aplikasinya (JPFA), 6(2), 44-50. 
Ramadhani, R. (2017). Kemampuan Pemecahan Masalah Matematika Siswa SMA Melalui Guided Discovery Learning Berbantuan Autograph. JPPM, 10(2), 72-81.

Sadeghi, H., Biniaz, M., \& Soleimani, H. (2016). The Impact of Project-Based Language Learning on Iranian EFL Learners Comparison/Contrast Paragraph Writing Skills. International Journal of Asian Social Science, 6(9), 510-524.

Salu, B. (2013). Pengaruh Strategi Penemuan Terbimbing terhadap Motivasi dan Hasil Belajar IPA Siswa Kelas IV SDN Rantepao I Kabupaten Toraja Utara. Jurnal Pendidikan Sains, 1(1), 85-91.

Sriwidiarti, D. (2016). Keefektifan Metode Penemuan Terbimbing dan Metode Pemberian Tugas pada Pembelajaran Bangun Ruang Sisi Lengkung. Jurnal Pendidikan Matematika Dan Sains, 4(1), 63-74.

Susanawati, E., Diantoro, M., \& Yuliati, L. (2013). Pengaruh Strategi Project Based Learning dengan ThinkQuest Terhadap Kemampuan Berfikir Kritis Fisika Siswa SMA Negeri 1 Kraksaan. Jurnal Pengajaran MIPA, 18(2), 207-213.
Susanti, Musdi, E., \& Syarifuddin, H. (2017). Pengembangan Perangkat Pembelajaran Matematika Materi Statistik Berbasis Penemuan Terbimbing Untuk Meningkatkan Kemampuan Pemecahan Masalah Matematis Materi Statistika. Jurnal JNPM ( Jurnal Nasional Pendidikan Matematika ), 1(2), 305-319.

Syafri, F. S. (2017). Kemampuan Representasi Matematis dan Kemampuan Pembuktian Matematika. Jurnal Edumath, 3(1), 49-55.

Tafakur, \& Suyanto, W. (2015). Pengaruh Cooperative Project-Based Learning terhadap Motivasi dan Hasil Belajar Praktik "Perbaikan Motor Otomotif" di SMKN 1 Seyegan. Jurnal Pendidikan Vokasi, 5(1), 117-131.

Widayati, Suyono, \& Rahayu, W. (2018). Pengaruh Model Pembelajaran Berbasis Penemuan Terhadap Kemampuan Berfikir Kritis Matematis Dan Self Concept Dengan Mengontrol Kemampuan Awal Peserta Didik Kelas VII SMP. JPP, 11(1), 94-104.

Yusnita, I., Masykur, R., \& Suherman. (2016). Modifikasi Model Pembelajaran Gerlach dan Ely Melalui Integrasi NilaiNilai Keislaman Sebagai Upaya Meningkatkan Kemampuan Representasi Matematis. Al-Jabar, 7(1), 29-38. 